\title{
The effect of agrotechnological factors and the cropping season on sweetcorn (Zea Mays L. convar. saccharata Koern.) production in a humid year
}

\author{
Ádám Lente \\ Centre for Agricultural And Applied Economic Scienses \\ Faculty of Agricultural and Food Scienses and Enviromental Managment \\ Institute of Crop Scienses \\ Debrecen \\ Böszörményi Str. 138 \\ lente@agr.unideb.hu
}

key words: sweetcorn, sowing time, fertilization, hybrid, plant density, yield

\section{SUMMARY}

We have examined the effect of three agrotechnological factors (sowing time, fertilization, crop density) and four genotypes on the yield of sweetcorn on chernozem soil in the Hajdúság region in 2009. The experiment was set up at the Látókép Research Site of the University of Debrecen. We have included two sowing times (27 April, 26 May), six nutrition levels (control, $N_{30}+P K, N_{60}+P K, N_{90}+P K, N_{120}+P K$, $N_{150}+P K$ ) and four genotypes (Jumbo, Enterprise, Prelude, Box-R) at two crop density levels (45 thousand ha' ${ }^{-1}$.

In the humid cropyear of 2010 the amount of precipitation exceeded the 30-year average by $184 \mathrm{~mm}$ in the cropping season; the average temperature exceeded the same by $0.8 \mathrm{C}$ on the average of the examined months. The circumstances were most favourable for sweetcorn production with the first sowing time, thus, this was when the yield of all hybrids was the highest.

With early sowing time, the highest yield (23437 $\mathrm{kg} \mathrm{ha}^{-1}$ yield) was obtained with Enterprise at 45 thousand ha-l crop density level at

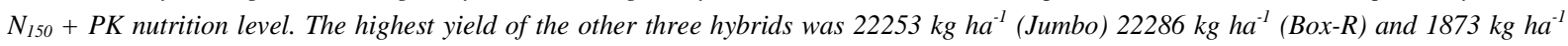
(Prelude). With the second sowing time, the highest yield was obtained with Enterprise again $\left(22237 \mathrm{~kg} \mathrm{ha}^{-1}\right)$ at 65 thousand ha $a^{-1}$ crop density level. With this sowing time the yield of Jumbo, Box-R and Prelude was $20888 \mathrm{~kg} \mathrm{ha}^{-1}, 17796 \mathrm{~kg} \mathrm{ha}^{-1}$ and $17401 \mathrm{~kg} \mathrm{ha}^{-1}$, respectively. We found that the highest yield was obtained at the highest nutrition levels $\left(N_{120}+P K, N_{150}+P K\right)$ with the first sowing time, while the same was obtained at lower nutrition levels $\left(N_{90}+P K, N_{120}+P K\right)$ with the second sowing time.

\section{INTRODUCTION}

Maize is the most important food and feed crop in the world with wide-range forms of use. The origin of maize (Zea Mays L.) is South America, its gene centre is where today is Chile and Peru.

The cultivation of maize is of great importance in Hungary as well, $32 \%$ of the arable land (1.2 million ha) is used for maize production.

Maize can equally be used in its green state as feed or processed into silage. Most of the maize is harvested at the stage of phisiological maturity, when the kernels are already dry. It is widely used for industrial purposes in the forms of edible oil, sugar, starch or ethanol.

In Hungary, maize production started at the beginning of the 19th century, however, it only gained significant land area in the 70's to satisfy the increasing need of canned sweetcorn production.

The global production area of sweetcorn is over 500 thousand ha. The biggest producer is the United States, where the production level is the highest as well.

In Hungary, the production area of maize was near 19 thousand ha in 2010, which is the highest within the European Union.

In Hungary, maize is produced on the highest acreage, in 2003 the production area reached 38 thousand ha, then it fell to 19 thousand ha in 2010. From this area $6 \%$ of the global maize production is harvested; at the same time, the contribution to the sweetcorn production of the Europena Union is $40-45 \%$. In the last two years the production area of sweetcorn was around 26 thousand ha, the average yields were $17.06 \mathrm{tha}^{-1}$ and $16.11 \mathrm{tha} \mathrm{h}^{-1}$ in 2008 and 2009, respectively. The production area in the Hajdúság region was 11 thousand ha, thanks to the fact that the calcerous chernozem soil is perfectly suitable for sweetcorn production.

Sweetcorn is very easy to be produced in biculture, for e.g . after peas. Except from where it is grown as a second crop, sweetcorn is harvested early, and it is considered as good or semi-good precrop for the following plant cultures.

Processed sweetcorn is available as canned corn or frozen corn. According to our data, $30 \%$ of the harvested maize is processed for frozen product and $70 \%$ is used for canned corn. Our canned corn export exceeded 60 thousand tons, while the frozen corn export was 30 thousand tons. 


\section{REVIEW OF SCIENTIFIC LITERATURE}

Sweetcorn is one of the subspecies of maize. It is different from feed grade corn in a recessive gene (sugary endosperm) on its 4th chromosome, by what the accumulated sugar cany only partially decompose (Balázs, 1994). The global land area of sweetcorn is around 500 thousand ha. The most important sweetcorn producers are the United States and Canada, but Hungary is also there in the top group with its export over 100 thousand tons (Zsombik-Daróczi, 2008).

According to Tracy (2001) sweetcorn can equally be used in raw or processed form. Due to the increasing demand its production has significantly increased in Europe, Asia and the United States, and the amount of processed corn has increased by $60 \%$ in the United States during the last 25 years (Williams et al., 2006). Comparing to other arable crops, the sowing period (three months or longer) of sweetcorn can be considered as the longest. It starts in the middle of April (early sowing) and ends at the beginning of July (late sowing) (Williams, 2008). According to Pereczes (1999) sweetcorn is a warm season crop, the germination would not start until the soil temperature exceeds $10{ }^{\circ} \mathrm{C}$. As regards the requirements of maize for heat, it can be grown in the whole country.

According to the new environmentally conscious farm advisory system, the specific nutrient content of an average $11 \mathrm{t} \mathrm{ha}^{-1}$ yield is as follows: $\mathrm{N} 10 \mathrm{~kg}, \mathrm{P}_{2} \mathrm{O}_{5} 4 \mathrm{~kg}, \mathrm{~K}_{2} \mathrm{O} 11 \mathrm{~kg}$ (based on Terbe et al, 2004).

The optimal crop density level of sweetcorn is determined by the variety and the environmental factors, furthermore, substantial nutrient supplementation is needed, for a $15 \mathrm{t}$ yield the fertilizer requirements are $100 \mathrm{~kg}$ nitrogen $(\mathrm{N}), 45 \mathrm{~kg}$ phosphorous $\left(\mathrm{P}_{2} \mathrm{O}_{5}\right)$ and $120 \mathrm{~kg}$ potassium $\left(\mathrm{K}_{2} \mathrm{O}\right)$ (Pereczes 1999). The specific fertilizer requirement is as follows: nitrogen $1210 \mathrm{~kg} \mathrm{ha}^{-1}$, phosphorous $80-100 \mathrm{~kg} \mathrm{ha}^{-1}$, potassium $100 \mathrm{~kg} \mathrm{ha}^{-1}$, which can be increased the stands are irrigated (Géczi, 2003).

Nigicser (1997) suggests that, depending on the nutrition supply of the soil, $60-80 \mathrm{~kg}$ of phosphorous and 80$100 \mathrm{~kg}$ of potassium fertilizer should be applied as base fertilizer before ploughing. In his experiment on soil cultivation and crop density, Akmar (2002) applied $80 \mathrm{~kg}$ phosphorous in autumn and $150 \mathrm{~kg}$ nitrogen in two steps in autumn and spring (8-10 leaf stage). According to Hodissi et al (2004) the crop density ranges between 40 thousand and 70 thousand crop ha ${ }^{-1}$ depending on the water supply.

Based on his experiments in 2005 and 2006, Kumar (2009) found that the most favourable conditions for sweetcorn production are 83 thousand crop ha ${ }^{-1}$ and $120 \mathrm{~kg} \mathrm{~N} \mathrm{ha}^{-1}$.

In 2005 in a research conducted by the OMMI (National Institute for Agricultural Quality Control) the average yield of the Australian breed Enterprise was around 19 t/ha both research plots (Kovács, 2006).

\section{MATERIAL AND METHODS}

The experiment was carried out at the experimental site of the University of Debrecen, Farm and Regional Research Institute, at Látókép. The site is situated near route 33 on the Hajdúság loess ridge. The soil of the research plots is calcerous chernozem with deep humus layer. The medium-heavy loam soil is of good condition.

In the earlier year winter wheat was produced on the research plots, which is an excellent precrop for sweetcorn.

In the experiment four commercially produced mid-season (Prelude) and mid-late (Jumbo, Enterprice, Box-R) sweetcorn hybrids were planted. Two of the varieties are of American (Jumbo, Box-R) and two are of Australian origin (Enterprise, Prelude).

All four hybrids were planted with two sowing times. The first (early) sowing time was 27th April 2010, the beginning of the main sowing period, the second was almost a month later, 26th of May, the end of the main sowing period.

In the experiment six fertilization levels and two crop density levels were examined. The six fertilization levels are as follows: control (untreated), $\mathrm{N}=30 \mathrm{~kg} \mathrm{ha}^{-1}, \mathrm{P}_{2} \mathrm{O}_{5}=22,5 \mathrm{~kg} \mathrm{ha}^{-1}, \mathrm{~K}_{2} \mathrm{O}=26,5 \mathrm{~kg} \mathrm{ha}^{-1}$ as base fertilizer and the twofold, threefold, fourfold and fivefold of it.

The crop density levels were 45 thousand $\mathrm{ha}^{-1}$ and 65 thousand $\mathrm{ha}^{-1}$.

The desing of the experimental plots was split-split spot designed in four repetitions. The size of the plots were $11.4 \mathrm{~m}^{2}$. The corncobs were harvested manually with the husk on.

Table 1 shows the precipitation and temperature values in the examined cropping year. As 2010 was humid and in terms of temperature average, the weather was neutral for sweetcorn production. As regards the early sowing period, the total precipitation was $339 \mathrm{~mm}$ (93 mm higher than the 30-year average) and the average temperature exceeded the 30-year average by $1.5 \mathrm{C}$ (April, May, June, July) in the cropping year. As regards the late sowing period, the precipitation surplus was $24.7 \mathrm{~mm}$ and the temperature was $0.7{ }^{\circ} \mathrm{C}$ higher (May, June, July, August). 
Meteorological datas of the cropyear (Debrecen, 2010)

\begin{tabular}{|c|c|c|c|c|}
\hline Month & Precipitation (2010) & 30 year average & $\begin{array}{c}\text { Temperature } \\
(\mathbf{2 0 1 0})\end{array}$ & 11,6 \\
\hline April & 83,3 & 42,4 & 16,6 & 10,7 \\
\hline May & 111,4 & 58,8 & 19,7 & 22 \\
\hline June & 100,9 & 79,5 & 15,8 & 19 \\
\hline July & 97,2 & 65,7 & 20,3 \\
\hline August & 98,3 & 60,7 & 17,8 & 19,6 \\
\hline
\end{tabular}

\section{EVALUATION OF THE RESULTS}

The yield capacity of hybrids is genetically determined. The yield capacity is also influenced by the cropping season and the applied agrotechnological factors.

In 2010 during the cropping season of sweetcorn (from April to August) the amount of precipitation was 184 $\mathrm{mm}$ higher than the 30-year average. In the first month of the sowing (April) the amount of precipitation was nearly double the 30-year average, while the temperature increased the same by $1{ }^{\circ} \mathrm{C}$. These circumstances were excellent for germination and seedling growth. In May (second sowing time) the precipitation was again near double the 30-year average, while the temperature was $0.8{ }^{\circ} \mathrm{C}$ higher. In the flowering time during the first growing season (the beginning of June) the temperature exceeded the 30 -year average by $1.7{ }^{\circ} \mathrm{C}$, while the amount of precipitation was 1.5 times higher. August was the only month when the monthly average temperature was lower than the average $\left(0.6{ }^{\circ} \mathrm{C}\right)$ but the precipitation was $31.5 \mathrm{~mm}$ higher than the average again. The high precipitation caused increased vertical movement of the nutrients in the soil, which had a negative effect on the nutrient intake of the plants.

The effect of some agrotechnological factors (sowing time, crop density, nutrient supply) and four genotypes were examined in small-plot experiment at the experimental site of the University of Debrecen, Farm and Regional Research Institute, at Látókép.

With early sowing, the lenght of the cropping year was 98 days (Prelude, Jumbo) and 101 days (Enterprise, Box-R), while with late sowing it was shorter, 86 days (Prelude) and 90 days (Jumbo, Enterprise, Box-R).

Considering each weather parameters and the yields, we found that the weather of the first sowing time was the most favourable for sweetcorn production. This is well reflected in the harvested amounts, i.e the amount of harvested corncobs with the husk. The moisture content of the kernels was 67-69\% at harvesting, which is the optimal for canned corn production.

Sweetcorn is plant of high nutrient requirment, which equally utilizes the nutrients already in the soil and the applied fertilizers as well. The effectiveness of fertilization is significantly influenced by the soil characteristics, the water supply, the genotype and the agrotechnological factors.

The effect of the agrotechnical factors on yield of sweetcorn in early main sowing time (27 April 2010) (Debrecen, chernozem soil)

\begin{tabular}{|c|c|c|c|c|c|c|c|c|}
\hline Plant density & $\begin{array}{c}\text { Hybrid }(A) \\
\text { /Fertilization }(B)\end{array}$ & $\emptyset$ & $N_{30}+P K$ & $N_{60}+P K$ & $N_{90}+P K$ & $N_{120}+P K$ & $N_{150}+P K$ & $L S D_{5 \%}$ \\
\hline \multirow{4}{*}{$\begin{array}{l}45 \text { thousand } \\
\qquad \mathrm{ha}^{-1}\end{array}$} & Jumbo & 12582 & 15395 & 15937 & 16809 & 17007 & 18487 & 3991(A) \\
\hline & Enterprise & 16612 & 19457 & 20428 & 22500 & 22105 & 23437 & 985(B) \\
\hline & Prelude & 12993 & 14062 & 16464 & 17286 & 18701 & 18734 & 1970(AxB) \\
\hline & Box $-R$ & 13618 & 14539 & 16595 & 17303 & 19276 & 17500 & - \\
\hline \multirow{4}{*}{$\begin{array}{c}65 \text { thousand } \\
\qquad \mathrm{ha}^{-1}\end{array}$} & Jumbo & 14296 & 15543 & 19030 & 20099 & 22253 & 21464 & $2000(A)$ \\
\hline & Enterprise & 16546 & 18536 & 20641 & 20444 & 23061 & 22204 & $1024(B)$ \\
\hline & Prelude & 12549 & 13553 & 13914 & 16957 & 18092 & 18618 & $2048(\mathrm{AxB})$ \\
\hline & Box-R & 14539 & 16760 & 20362 & 21102 & 22056 & 22286 & - \\
\hline
\end{tabular}

In the experiment the optimal fertilization level of the hybrids was examined at different fertilization levels. In tables 2 and 3, the bold values show the agroecological requirement of the hybrids. The agroecological optimum is the highest fertilizer level, after which the yield cannot be increased significantly anymore. This level was the highest in the case of Enterprise with both sowing times, $23061 \mathrm{~kg} \mathrm{ha}^{-1}$ with the first sowing time and $22237 \mathrm{~kg} \mathrm{ha}^{-1}$ with the second sowing time. 
Out of the four hybrids, with the first sowing time Prelude had the lowest maximum yield at $18618 \mathrm{~kg} \mathrm{ha}^{-}$ ${ }^{1}$ with the first sowing time and $17056 \mathrm{~kg} \mathrm{ha}^{-1}$ with the second sowing time.

Comparing the average yields of the hybrids at the control and agroecological fertilization levels, significant difference was found only between Enterprise and the other two hybrids with the first sowing time and at low crop density level. Considering the yield responses at the agroecological fertilization level, at higher crop density level we found significant difference between Jumbo, Enterprise, Prelude and Box-R.

The effect of the agrotechnical factors on yield of sweetcorn in late main sowing time (26 May 2010)

(Debrecen, chernozem soil)

\begin{tabular}{|c|c|c|c|c|c|c|c|c|}
\hline Plant density & $\begin{array}{c}\text { Hybrid }(A) \\
\text { /Fertilization }(B)\end{array}$ & $\varnothing$ & $N_{30}+P K$ & $N_{60}+P K$ & $N_{90}+P K$ & $N_{120}+P K$ & $N_{150}+P K$ & $L S D_{5 \%}$ \\
\hline \multirow{4}{*}{$\begin{array}{l}45 \text { thousand } \\
\qquad \mathrm{ha}^{-1}\end{array}$} & Jumbo & 13470 & 15724 & 17056 & 17730 & 18454 & 16414 & 2727(A) \\
\hline & Enterprise & 16266 & 17714 & 17993 & 18536 & 18273 & 18635 & 1134(B) \\
\hline & Prelude & 14918 & 15115 & 16036 & 16332 & 17401 & 16266 & $2267(\mathrm{AxB})$ \\
\hline & Box $-R$ & 15559 & 16447 & 17599 & 17796 & 17434 & 17237 & - \\
\hline \multirow{4}{*}{$\begin{array}{l}65 \text { thousand } \\
\qquad \mathrm{ha}^{-1}\end{array}$} & Jumbo & 18289 & 18882 & 18980 & 17845 & 20888 & 18602 & 2132(A) \\
\hline & Enterprise & 18306 & 19687 & 21546 & 20444 & 21546 & 22237 & 1214(B) \\
\hline & Prelude & 14101 & 15115 & 15493 & 17237 & 16891 & 16678 & $2428(\mathrm{AxB})$ \\
\hline & Box-R & 11628 & 14227 & 14178 & 14457 & 17056 & 15312 & - \\
\hline
\end{tabular}

The control and agroecological fertilization levels were compared on the average of the two sowing times and the two crop density levels applied. The difference was highest at Box-R with $5267 \mathrm{~kg} \mathrm{~kg} \mathrm{ha}^{-1}$ yield, while this rate was slightly lower at Jumbo $\left(5181 \mathrm{~kg} \mathrm{ha}^{-1}\right)$. In case of the other two Australian breeds, the difference was cca $800 \mathrm{~kg} \mathrm{ha}^{-1}$ less, i.e. $4446 \mathrm{~kg} \mathrm{ha}^{-1}$ (Enterprise) and $4358 \mathrm{~kg} \mathrm{ha}^{-1}$ (Prelude). These values reveal that the the two American breeds (Jumbo and Box-R) utilized the fertilizers better than the other two hybrids. At the control fertilization levels with each sowing time and at each crop density level Enterprise had the highest yield (16612 $\mathrm{kg} \mathrm{ha}^{-1}$ and $18306 \mathrm{~kg} \mathrm{ha}^{-1}$ ). According to these values, Enterprise utilized best the natural nutrition supply of the soil.

Analize of the agrotechnical factors in sweet corn

Table 4 (Debrecen, 2010)

\begin{tabular}{|c|c|c|c|c|c|c|c|c|}
\hline \multirow{2}{*}{$\begin{array}{c}\text { Sowing time } \\
\text { Hybrid }\end{array}$} & \multicolumn{4}{|c|}{ I. sowing time } & \multicolumn{4}{|c|}{ II. sowing time } \\
\hline & Jumbo & Enterprise & Prelude & Box $-R$ & Jumbo & Enterprise & Prelude & Box-R \\
\hline $\begin{array}{c}\text { Controll (avrage of plant } \\
\text { densities) }\end{array}$ & 13440 & 16579 & 12771 & 14079 & 15880 & 17286 & 14509 & 13594 \\
\hline$N_{o p t .}+P K$ & 135 & 105 & 150 & 135 & 120 & 90 & 105 & 105 \\
\hline $\begin{array}{c}\text { Max. yield (avrage of plant } \\
\text { densities) }\end{array}$ & 20370 & 22781 & 18676 & 20781 & 19309 & 19976 & 17319 & 17426 \\
\hline $\mathrm{kg} / \mathrm{mm}$ (controll) & 41,2 & 50,8 & 39,1 & 43 & 40,6 & 44,2 & 37,1 & 34,7 \\
\hline $\mathrm{kg} / \mathrm{mm}\left(\mathrm{N}_{\text {opt. }}+\mathrm{PK}\right)$ & 62,4 & 69,8 & 57,2 & 63,7 & 49,3 & 51 & 44,2 & 44,5 \\
\hline
\end{tabular}

Examining the first sowing time, we found that Prelude had the highest agroecological fertilization optimum $(150 \mathrm{~kg})$ while this value was lowest $(105 \mathrm{~kg})$ with the highest yielding Prelude. The agroecological fertilization optimum of Jumbo and Bor-R was $135 \mathrm{~kg}$ with the first sowing time. As regards the second sowing time, the agroecological fertilization optimum was lower for all the four hybrids. Jumbo had the highest value $(120 \mathrm{~kg})$, while the lowest was of Enterprise, similar to the first sowing time $(90 \mathrm{~kg})$. The agroecological fertilization optimum of the other two hybrids was $105-105 \mathrm{~kg}$.

We have analysed the yield per $1 \mathrm{~mm}$ of precipitation. Table 4 shows that this value was highest with the first sowing time. The yield per $1 \mathrm{~mm}$ of precipitation ranged between $34.7 \mathrm{~kg} / \mathrm{mm}$ and $50.8 \mathrm{~kg} / \mathrm{mm}$ on the control plots. When we calculated the yield per $1 \mathrm{~mm}$ precipitation for the agroecological fertilization optimums, the values ranged between $44.2 \mathrm{~kg} / \mathrm{mm}$ (Prelude, second sowing time) and $69.8 \mathrm{~kg} / \mathrm{mm}$ (Enterprise, first sowing time). These values reveal that Enterprise has the best water utilization capacity. 


\section{CONCLUSIONS}

In the humid year of 2010 the effect of agroechnological factors on the yield of four sweetcorn genotypes were analysed. We found that the weather of the first sowing season was more favourable for sweetcorn. All four hybrids gave the highest yield in this case. The amount of precipitation was significantly higher than the 30 -year average, and by washing the nutrients deeper down in the soil it had a negative effect on the yields with the second sowing time. At the same time, with the first sowing time, which was more favourable for sweetcorn, thanks to the good water supply, the yield difference resulted from the different crop density levels disappeared, because the lower crop density was compensated by developing a second corncob. We did not experience the same with the later sowing time, when the highest yields were obtained at the higher crop density levels for all four hybrids. As regards the effect of fertilization, we found that with the first sowing time the highest yields were obtained at the higher fertilization levels at both crop density levels, while with the second sowing time the maximum yield was obtained at the lower fertilization level.

Examining the two sowing times and the agrotecnological factors, we found that Enterprise had the highest yield. Considering the agroecologically optimal fertilization levels, Enterprise had the lowest fertilizer requirement in the specific cropping year. On the average of the crop density levels, the yield of Jumbo and Box-R was above $20 \mathrm{t}$ with the first sowing time. With the second sowing time, the yield of Jumbo was $19 \mathrm{t}$, while the yield of Prelude and Box-R was above 17 tons. 
Akmar Z.: 2002. Effect of tiller removing and plant density on ear yield of sweet corn (Zea mays saccharata Sturt). Pakistan Journal of Biological Sciences. 5: 9. 906-908.

Balázs S.: 1994. Zöldségtermesztők kézikönyve. Mezőgazda Kiadó, Budapest. 631-639.

Gécz L.: 2003. Piacos Zöldségtermesztés. Szaktudás Kiadó Ház, Budapest. 128-133.

Hodossi S. -Kovács A. -Terbe I.: 2004. Zöldségtermesztés szántóföldön. Mezőgazda Kiadó, Budapest. 340-348.

Kovács F.: 2006. A 2005. évi csemegekukorica leíró kísérletek, OMMI. Kertészet és szőlészet. 55: 18. 6-8.

Kumar A.: 2009. Production potential and nitrogen-use efficiency of sweet corn (Zea mays ) as influenced by different planting densities and nitrogen levels. Indian Journal of agricultural siences. 79: 7. 351-355.

Nigicser T.: 1997. Csemegekukorica. Magyar Mezőgazdaság, 52: 38. 30-31.

Pereczes J. 1999. Csemegekukorica. In: Mártonffy B., Rimóczi I. (Szerk.) Nagymagvú zöldségfélék. Budapest., Mezőgazda Kiadó, 50-72. p.

Terbe I., Slezák K., Kappelen N. (2004): A talajművelés és tápanyag-utánpótlás helyzete a szántóföldi zöldségtermesztő gazdaságokban. Gyakorlati Agrofórum, 12 (1) 2-6.p.

Tracy, W.F.: 2001. Sweet corn. FL: CRC Press. 155-197.

Williams, Martin M.: 2008. Sweet corn growth and yield responses to planting dates of the north central United States. Hortscience, 43 : 6. 1775-1779.

Williams, Martin M. -Masiunas, B. J.: 2006. Functional relationships between giant ragweed (Amrosia trifida) interference and sweet corn yield and ear traits. Weed Science, 54: 54. 948-953.

Zsombik L.-Daróczi M..: 2008. A csemegekukorica termesztésének helyzete és aktualitásai. Agrárágazat. 9: $2.24-26$. 